\title{
Indigenous Dance and the Nation: Conflation and Metonymy
}

It is interesting, as a Kiwi living in Europe, to understand the ways in which New Zealand is perceived to those outside its borders. When I tell people I am from Aotearoa, their immediate reaction is to identify the country with images: beautiful scenery, the Lord of the Rings movies, sheep, and in particular rugby and the Haka. This ubiquitous image of the All Blacks performing a particular sequence of movement and sound before executing a performance of skill and strategy within the strict confines of an improvisational game is one explored by Stephen Jackson and Brendan Hokowhitu in their 2002 article Sports, Tribes and Technology: The New Zealand All Black Haka and the Politics of Identity. They suggest the conflation of rugby, the Haka and national identity is a deliberate representational strategy. While Jackson and Hokowhitu concentrate on the commercial aspects of this strategy, there is also a strong and present governmental presence within these representational strategies also.

The task of this piece of writing is to start to untangle and explore some of those strategies: the ways in which the nation-state works with indigenous and folk dance, especially contemporary indigenous dance in post-colonies. How nation-states engage with indigenous dance to promote a particular image and identity both internally and abroad can be seen as a collection of processes through which a nation-state utilises minority identities as a metonym for a larger, more dominant culture that may or may not exist. At the same time, conflation can occur, tying in the chosen minority identity with a larger, wider cultural identification within the nation-state. This can create the illusion of internal cultural cohesion, and can sometimes obscure historical processes, implying a past that never existed, or simplifying complex relational structures within, and between 
cultures both inside and outside the nation-state to create a construct that comes to stand for the nation-state.

In this article, I concentrate primarily on the experience in the Philippines as this is where the majority of my own recent research has taken place. However, over the past few years I have lived and worked in a number of other countries and some observations concerning the connections between the nation-state and minority indigenous dance in some of these countries are pertinent, especially from within New Zealand. This pulls together the threads of my own experience, and utilises existing patterns of thought from academics around the world.

In order to do this, I must first discuss a little of my own subject position, and the sorts of approaches I bring to the research.

I am both a performance practitioner and a researcher, currently working in an English university. This is important mostly because it means I fall into the trope discussed by Edward Said in his groundbreaking book, Orientalism (1979). I am a 'Westerner', funded by a 'western' institution producing work concerning both 'western' and 'non-western' countries. As such I have had to adopt strategies to justify my research, and to ensure my voice is not the only, or most important voice heard in my work.

In essence I utilise many features of the Altermodern as articulated by Nicolas Bourriaud in his manifesto, published as part of the Altermodern exhibition at the Tate Modern in 2009. Bourriaud describes the Altermodern artist as a cultural nomad; a flâneur who uses his/her flânerie to make work and derive knowledge (2009: 3). His organising concept is that of the archipelago, and he sees Altermodern artists moving through a centre-less archipelago, revealing, as they create, a layered and complex intertwining of localities, times and networks of meaning.

According to the dance critic Lena Hammergren, the flâneur is associated with '...the detached gaze of the foreign visitor' (1996: 54). This characterises my own role in both my practice and research; the traveller who observes and learns, but is relatively untouched by the different cultures around him. 
As a researcher, my work is interdisciplinary. I draw from several different academic fields, including performance studies, cultural studies and anthropology, adhering to the position that many of the distinctions we make between disciplines are constructed in order to 'protect' the discipline, and that by working across fields of thought, we can cross-fertilise ideas and gain a greater understanding of the problems we encounter. As an academic, my work is, in general, practice-based. This means I have the freedom to move across and through disciplines, finding and using what is useful to the work; as such, moving between the islands of the academic archipelago, creating links, making connections and forging meaning.

My work is generally concerned with culture. Although in academia there is no consensus as to what culture actually is, and there are divisive and important differences between disciplines, there is some consensus in some areas of culture and representation. James Clifford (1986), discusses how culture can be seen to be composed of seriously contested codes and representations. He continues to discuss the way we construct truths within a culture, and how this is made possible by powerful 'lies' of exclusion and rhetoric. In other words, what is represented as part of a culture is not straightforward, but rather contested and the site also of exclusion - for something to represent a culture, something else has to 'not' represent it.

Robert J. Foster, in Making Cultures in the Global Ecumene (1991) discusses the construction of entire nations as cultural products, which are then marketed both to the external world and internally. $\mathrm{He}$ considers that the production of national culture involves a certain amount of identification of criteria to exclude those who live beyond the borders of the nation-state; the 'other' without an essential identity. Within the nation-state, the self-conscious creation and dissemination of representations - the staging of contests between competing groups - results in a discourse of corruption, pollution and purity which accompanies any attempt to imagine the national community.

According to Foster, official histories appropriate and revalue local traditions to make them fit a specific concept of national 
identity. That national identity is carefully controlled and manipulated, as it is a valuable commodity in a global market.

Through processes of selection, revision and invention, competing agents simultaneously construct idealised images of the nation and authority, and the national past is constructed as continuous and inevitable. Frequently too, the past is mythologised, and the time 'before' industrialisation, colonisation and modernisation becomes the scene of perfect national identity that 'we' can never get back to; a type of authenticity that has been taken from us by the modern world, and more specifically the processes of modernity (Stavrakakis and Chrysoloras: 2006) . Social memory becomes individually incorporated in and through ritual performances.

Foster also notes that the construction of national identity is an ongoing process, one that never is completed, although, he adds, that 'The very notion of a nation with a fixed, 'given' cultural identity is a sign of the success of a whole array of practices in actualising that identity' (1991: 238)

National identity, undergoing the processes described by Clifford and Foster, becomes a brand; a unique selling point in a world where difference can be a deciding factor in the profile of a nation state in terms of tourism, international recognition, and even 'soft' political power. National identity becomes a point of pride, a point of reference for those inside and outside the physical boundaries, a shared imaginary of an impossible, ever-changing construct.

In the cause of national identity, Foster argues, sameness overrides difference. This emphasis on sameness means the competition to represent the nation is fierce, the field of 'not' representing huge. Barbara Kirshenblatt-Gimblet, in Destination Culture (1998), also discusses this idea of difference and sameness, in relation to the performance of cultural fragments by national troupes. She discusses how we look at cultural fragments, such as dance. She makes the point that these fragments were never originally constructed to represent an entire culture, but, over time, have changed their significance. As such, they have become a metonym, standing in for a culture as a whole. 
National troupes typically perform traditions from across the land, no matter what the personal histories of the performers. Since everyone can perform everything and everything belongs to everyone, differences do not differentiate. Difference is reduced to style and decoration, to add spice to life. (1998: 65)

This brings up questions round the function of a national troupe. If the function of the dance within the context of a national company is to exhibit the cultural history of the nation, this fails. The very idea of a national dance company implies that it is indeed possible for the nation to be represented by one company, and that one company, within its structures, somehow mirrors the nation in terms of identity of the participants, choice of performance materials and genre of performance. Already this starts to bring up difficulties; often both performers and administrators have international origins, the choice of performance materials is individual and often reflects the market rather than the nation, and the genre of performance can be very particular to the company. Instead of a representation of the nation at any level, what can often be seen is a potted history of the struggle to represent that which cannot ever be fully represented: the struggle for identity. Kirshenblatt-Gimblet's ideas, however, show a strong bias in favour of lineage; the performance of culture as a sequential process moving through time from one culture, becoming subsumed into another culture, and altered to fit the narratives of nation-hood. This idea also takes into account globalisation and the inevitable, ubiquitous cross-fertilisation of culture that occurs and has been occurring for centuries. In The Ilusion of Cultural Identity (2005), Jean-François Bayart discusses the idea that culture is developed dialogically between two forces; tradition and innovation; the tradition hiding the innovation. This dialogic has been occurring for quite some time, and has grown hand-in-hand with colonisation.

With the story of the nation as a backdrop, Anthony Shay, a leading folk dance academic, explains how traditional dance functions. 
...the very choice of traditional dance, arguably the most visually spectacular form of performance expression, showing an innocent youth engaged in wholesome folk activity, actually achieves the highly political choice of depicting and representing the nation in its essentialist entirety in this "non-political", "innocent" cultural fashion. (1998: 29)

So folk and indigenous dance becomes essentialised and highly politically charged through the act of becoming chosen, and frequently adapted and decontextualized to represent the nation. It is easy, and politically astute, to attribute 'essential' qualities to a nation of people through indigenous dance. To believe this has any sort of academic base, however, is somewhat naïve.

To illustrate, in 2006 I was commissioned by Trade and Industry New Zealand to choreograph a new suite of dances, entitled She'll be Right to represent New Zealand for the Waitangi Day celebrations in Manila, in the Philippines. The arm of the New Zealand government responsible for encouraging commerce selected the medium of dance to represent and promote the country. The selection criteria were simply that I was a New Zealander, living in the Philippines, and artistic director of a highly reputable dance company there. There was an assumption that because I was a Kiwi, that I knew and understood the whole range of cultural codes that make up New Zealanders and that I was capable of translating and reducing those codes into a 20 minute dance suite, incorporating a fashion show. There was an assumption that the dance suite would be an acceptable way to represent the whole country, internationally, on one of its most important commemorative days. Dance became a ritualised way of remembering, and more importantly, imagining the country. Furthermore, I accepted this without questioning at the time, as many have before me and after. An accident of birth made me eligible to create a representation of 'my' country; I never considered whether or not I should make that representation. That 
representation has been seen and consumed by an audience (and performers) and has influenced how many people in the Philippines now understand and engage with the idea of New Zealand.

When faced with the challenge the commission presented, my response was to make a highly personal piece of dance; I selected aspects of my life in New Zealand and used them as a base for movement ideas, which I then developed, refined and arranged in sequence to allow ideas to flow through. However, of course, variables included the Filipino dancers I was working with, their styles of training, and what I could achieve with them within the time frame of the rehearsal process.

One of the other points Anthony Shay (Ibid) makes is that dance is an excellent medium to explore national identity. Because of its spectacular nature, it can be a transparent medium through which to observe cultural change. This can be seen in She'll be Right, where I explored concepts of 'Kiwi-ness' that were entirely subjective. These concepts were also influenced by the location: the Philippines, and the sense of 'otherness' I experienced there. In effect, the work concerned ideas around 'foreignness' just as much as 'Kiwi-ness'. In effect it was an Altermodern performance. However, the impact of conflation on the work meant that for the audience and performers She'll be Right was an authentic representation of New Zealand culture.

Conflation can be seen as the process through which one thing is associated, and comes to stand for, or represent, another. Indigenous dance tends to be specific to a particular locality or region, and often was created in response to very particular stimulus within that locality. Traditional indigenous dance, with exceptions, has been transmitted, until recently, as part of a living, breathing, evolving culture. As such the dances have changed in their significance. Representation starts to come into the picture with the concept of anthropology and ethnography; the study of the 'other' and 'same'. Suddenly indigenous dance, along with many other aspects of living, becomes part of an 'identity'. This concept of identity becomes inscribed in written material, just as the dance becomes inscribed on the bodies of the participants. Culture becomes a marker of 
difference, a way of distinguishing the 'us' from the 'other', while fragments of that culture become adopted as metonyms of what is often a larger, unrelated, or tangentially related culture.

However, identity is not simply a matter of choice, although choice can affect identity. In an intercultural world it can seem that identity has become part of the marketplace, where we select, purchase and perform the identity we choose. Richard Schechner proposes this idea as a 'culture of choice' where one is born into a homogenous world culture, but one can choose to identify with particular cultures (1996: 49). Scheckner considers we are moving towards this 'culture of choice'. It appears to be a process that is occurring at present. On the other hand, the luxury of choice is something that is very much associated with the 'western' world, and could be equated also with wealth. In places where poverty is rife, people often have little or no choice in many areas of their lives, and are not aware of the choices they may have. Indoctrination also lessens choice, especially indoctrination from the nation-state, claiming cultural superiority over other nation-states or areas. A culture too places restrictions upon membership; restrictions based on criteria, which involve a very wide set of variables, including place of birth, gender, ethnicity of parents, wealth, class and so on. Identity becomes contingent on circumstance. To move beyond the mind-sets programmed into us by circumstance is a challenge for all of us.

It is in the interests of the nation-state for its citizens to identify with the state itself. In many ways this is self evident, for in a very real sense the nation-state is comprised of 'imagined communities' (Anderson 1990). People construct the nation-state mainly through a sense of shared values, language and aspirations. Yet while the people construct the nation- state, frequently the government attempts to manipulate the bonds which bind the state together. One of the main bonds is culture, and dance is a part of this. The strategies through which dance becomes chosen to represent the nation are many and varied. One of the principle means is through national arts funding agencies, who, directly and indirectly select and fund work that comes to stand for the nation. Even the act of the government funding certain arts organisations can give status. At the 
most basic level, arts councils, such as Creative New Zealand or the Arts Council England have very specific criteria that govern their selection of what gets funded and what does not (http://www.artscouncil.org.uk/funding/grants-arts/how-apply/, http://www.creativenz.govt.nz/en/getting-funded/results-we-arelooking-for ).

That selection criteria can come from several different sources: governmental direction, from internal top-down direction, from individual arts officers interpreting direction and occasionally from consultation with the industry and community. Because there is limited public funding, priorities are drawn-up, often reflecting the cultural background and value of those drawing up the priorities. Hence in the UK, arts administration and 'high' art are frequently funded, as they are valued by the people drawing up the funding priorities.

However, selection can also come from within a community, or from the commercial sector. As demonstrated already, these can also be an extension of governmental influence; the government gives funding to an agency, who gives it to a community organisation, who, operating under the criteria given as part of the funding package, decides on what will represent the nation as a whole.

The selection of who and what will represent a nation comes further into focus when considering the chain of power, specifically the role of those who make the decisions concerning what will represent the nation state. Felicia Hughes-Freeland sees a disjunction between the interests of those who comprise a culture and those who make the decisions.

When those in power talk about culture, their interest is not in the purportedly long-standing and enduring practices per se, but rather in shifting these practices to address the needs of the present and the future. (2006: 57)

While there is nothing necessarily wrong with this, it does beg the question of who really decides what the needs of the present and the 
future actually are. The ways in which governments can manipulate culture are widespread.

While this sort of process is frequently undetectable, or even hidden from public scrutiny, occasionally this debate over how a nation is represented comes into focus in a very clear light. One such occasion was during the decision which dance should be the national dance of the Philippines, during the 1970s. At this point in time a debate was had whether the Cariñosa or the Tinikling should be the national dance.

The national folk dance company of the Philippines, Bayanihan, divided up folk/indigenous dance into 5 different suites in the 1940s. Each suite contains a number of dances taken from a particular geographic region, or community (Santos 2004). These range from the Muslim Suite, where the dances mostly come from the south of the country, to the Cordillera Suite, representing the peoples of the Cordillera range of mountains in the north. The Cariñosa is a dance that has a very concrete cultural base. It is part of the Maria Clara Suite of dances, which are the dances of the lowland, urbanised Christianised Filipinos. These dances had their origins in Europe, but had come to symbolise a Filipino system of courtship, specifically the 'no touch' rule: if you touched your partner during the dance, it was a scandal, and you would have to marry. The Cariñosa seems to exist as a colonial teaching tool; to teach, and enforce, a European version of romantic love and courtship exported to the Philippines, but taken and adapted to particular circumstances. The public nature of the dance, especially during its heyday in the late 19th and early 20th century, meant that it became a public display of heterosexuality and religious orthodoxy. Franscesca Reyes Aquino (1945), discusses how 'over-danced' Cariñosa was. She proclaimed it to be the national dance of the Philippines because of its popularity. Ramon Obusan (2003), however, discusses how the dance was rejected as the national dance of the Philippines because it was '...not the appropriate dance to exemplify the Philippine character, sensititvity, norms and values.' (2003: 19). Basilio Esteban Villaruz, one of the Philippines leading dance academics, has proclaimed the 
Tinikling as the 'unofficial' national dance because of its current popularity (2006).

So Tinikling has become the national dance. The provenance of Tinikling is quite different from the Cariñosa. It is from the Rural Suite, which are dances (as you might imagine) from the countryside. Tinikling is a dance that grew from several activities; catching the legs of birds in the fields, which developed into a children's game. This developed into a national dance involving jumping in and out of clashing bamboo poles. So here you can see very clearly the competition between two rival dances to represent the nation: a dance that clearly reflected a colonial, nostalgic, 'Western' viewpoint, and a dance that developed out of agriculture and survival mechanisms. Tinikling also reflects a practice, specifically with bamboo poles, that can be seen as more Asian in focus than the more 'western' Cariñosa: there are examples of indigenous dances involving bamboo poles in many countries from within Asia. While Tinikling won as a representative dance, it does not represent the civil war that is currently taking place In the Southern Philippines. It doesn't represent the multitude of problems or pleasures of the modern Philippines. Instead it conjures up a bucolic idyll. While some academics, notably Sally Ann Ness (1996) and Berenice Varona (2009), have given deeper and more subtle interpretations of the dance, its primary attribute, according to Franscesca Reyes Aquino (1945), is fun.

Once the representation is chosen, it is adapted for consumption. Again a process that can be seen with the example of the Tinikling, which was taken from the villages and towns of the lowland Philippines, adapted for the Western stage and made famous by the Bayanihan, the national folk dance company of the Philippines, who, for many years, performed the Tinikling as a way of finishing both their international and domestic performances of folk and indigenous dance (Santos 2004). It has then moved into the repertoire of most tourist dance companies, as a staple performance which can involve audience participation. The dance lends itself to this kind of treatment in some ways; in its simple form, the dance is easy to pick up and perform. 
As such the dance becomes a way of interacting with 'Filipinos', as well as a strong marker of identity for those overseas Filipino workers, who go to see the Bayanihan performances on their many international tours. Thus the performance of Tinikling, both by the people of the Philippines, the dance companies that utilise it, and by those attempting to negotiate the Philippines as 'foreigners' or 'tourists' becomes a kind of dancing of the nation, a physical exploration of a kind of standardised, essentialised identity wrapped up in an exterior of fun, and innocence.

\section{Conclusions}

The relationships between the nation-state and indigenous and folk dance are complex. The simplicity and seemingly innocent images that folk and indigenous dance conjure up conceal relationships based on power and control, which then feed back into the dance, giving it status and increasing popularity, yet also eradicating difference as anything more meaningful than decoration, and turning dance into a product for consumption in the international arena. Representation becomes an issue when a minority identity becomes conflated, through dance, with the majority cultural identity, sometimes losing the distinctive identity that drew national attention in the first place, and creating a false sense of belonging, obscuring the processes of history. 


\section{References}

Anderson, Benedict (1991) Imagined Communities: Reflections on the Origin and Spread of Nationalism London: Verso

Arts Council England (No Date Available) How to Apply available at http://www.artscouncil.org.uk/funding/grants-arts/how-apply/ [accessed 09/01/2015]

Bayart, Jean-François (2005) The Illusion of Cultural Identity University of Chicago Press: Chicago

Bourriaud, Nicolas (2009) Altermodern Tate Publishing: London (Programme notes)

Buckland, T (Ed.) (2006) Dancing from Past to Present

Clifford, James and Marcus, George (Eds.) (1986) Writing Culture University of California Press :London

Creative New Zealand (No Date Available) Results we are Looking For available at http://www.creativenz.govt.nz/en/gettingfunded/results-we-are-looking-for [accessed 9/01/2015]

Foster, Robert J, (1991) 'Making Cultures in the Global Ecumene' in Annual Review of Anthropology Vol 20 pp235-260

Hammergren, Lena (1996) 'The Re-turn of the Flâneuse' Corporealities Foster (Ed.) Routledge: London and New York

Jackson, Steven J and Hokowhitu, Brendan (2002) 'Sports, Tribes and Technology: The New Zealand All Black Haka and the Politics of Identity' Journal of Sport and Social Issues Vol 26 No. 2 (pp. 125139)

Kirschenblatt-Gimblett, Barbara (1998) Destination Culture: Tourism, Museums, and Heritage University of California Press: Los Angeles, London, Berkeley

Ness, Sally Ann (1996) 'Dancing in the Field' Corporealities Foster (Ed.) Routledge: London and New York

Obusan, R (2003) 'Tinikling' in Sayaw: Dances of the Philippine Islands Volume vi Guillem, Josefina B.(Ed.) Philippine Folk Dance Society: Manila pp19-24

Said, Edward (1991 (1979)) Orientalism Penguin Books: London

Santos, Isabel A (2004) Bayanihan, The National Folk Dance Company of the Philippines: A Memory of Six Continents Anvil Publishing: Pasig City

Schechner, Richard (1996) 'Interculturalism and the Culture of Choice' The Intercultural Performance Reader Pavis (Ed.) Routledge: London and New York

Shay, Anthony (1999) Choreographic Politics: The State Folk Ensemble, Representation, and Power paper presented at Manila International Dance Conference: Manila (pp. 28-43)

Stavrakakis, Yannis and Chrysoloras, Nikos (2006) '(I Can't Get No) Enjoyment: Lacanian Theory and the Analysis of Nationalism' Psychoanalysis, Culture and Society 11 Palgrave Macmillan Ltd. (pp. 144-163)

Tolentino, Francisca Reyes (1945) Philippine National Dances Kayumanggi Press: Quezon City 
Varona, Berenice P. (2009) 'Dance Fever' The University of the Philippines Forum Hidalgo (Ed.) Vol 10 Number 5 (pp. 14-15)

Villaruz, Basilio Esteban S. (2006) Treading Through: 45 Years of Philippine Dance Quezon City: University of the Philippines Press. 